\title{
Russian Megalopolis: Processes of Divergence, Separation and Integration of its Agents
}

\author{
Oleg Yanitsky", Ph.D. \\ Professor, Leading researcher at lab 'RSF-17-45-VP' of the Institute of Social Philosophical Studies and Mass \\ Communication of Kazan Federal University, Chief Researcher at the Federal Center of Theoretical and \\ Applied Sociology of the Russian Academy of Sciences., Moscow, Russia.
}

\begin{abstract}
*Corresponding Author: Oleg Yanitsky, Professor, Leading researcher at lab 'RSF-17-45-VP' of the Institute of Social Philosophical Studies and Mass Communication of Kazan Federal University, Chief Researcher at the Federal Center of Theoretical and Applied Sociology of the Russian Academy of Sciences., Moscow, Russia. Email: oleg.yanitsky@yandex.ru
\end{abstract}

\begin{abstract}
Drawing on the analysis of international theoretical literature, Russian media-content and my own long-term field researches (1975-2010) the article analyzes the processes of divergence, mutual isolation and integration of agents of contradictory transformations of Russian megalopolises under the impact of national and global factors. The major agents of these transformations are power structures, business, media, civil organizations and urban residents as such that pursue their particular interests. For the powers the megalopolises are the nests of their existence, for business they are an environment of their residence and gaining profit, for the media - an object for manipulation and propaganda of consumer way of life. Ordinary residents have very little means for making their life more comfortable, safe and ecologically-sound. As a result of activity and domination of power-business tandem an urban space is divided into isolated zones by the criterion of power and influence. The powers, business and activity of the rich is concentrated in central, historically most valuable areas of megalopolises while an ordinary people and migrants are resettled to urban periphery. Nevertheless, their mutual interdependence in the frames of a restricted urban area allows me to consider any megalopolis as contradictory but highly-integrated sociobiotechnical system (hereafter the SBT-system). This integration is implemented by various metabolic processes irrespectively to the wills of the above agents. Therefore, the megalopolises are simultaneously the driving forces of global development and the most vulnerable sites of the nation-states. Nowadays the grassroots and other civil initiatives are one of the political agents aimed at making the megalopolises more comfortable, safe and ecologically-sound for all.
\end{abstract}

Keywords: Business, Divergence, Globalization, Isolation, Integration, Media, Megalopolis, Metabolism, Ordinary People, Politics, The Rich, The SBT System, Urban Residents

\section{Posing The Question}

In the period of last 30-40 years the issue of megalopolises came to the forefront across the world. On the one hand, these mega-cities have become the centers of economic and political life not only of the nation-states but of the world as a whole. In the year of 1991, S. Sassen (1991) indicated that foreign investments and follows of immigrants gave the rise to global cities and provoked class and spatial polarization in them. Besides, by the neat remark of Sassen (2000), the double-sided process has been going. The planning structure of megalopolises has changed not seriously and very slow while their multi-sided activity has become more globally governed and economically and politically mobile.

On the other hand, an impact of the Fourth industrial revolution these cities as such and especially their micro structures undergo substantial transformations generated by all-embracing and allpenetrating influence of IT-structures and networks. At the same time an interdependence of natural, social, political and technological structures and processes has become so intensive and obvious that allowed me to move forth the concept of our planet as the global SBT-system and to consider the network of megalopolises as its carrying structure (Yanitsky, 2016). It turned a researcher's thought toward the numerous metabolic processes between qualitatively different agents, political, social or natural.

Finally, as I've mentioned earlier, a time-space regime of the coexistence of these qualitatively different agents turned into the other very acute research question, namely how and in what time- 
space regime they coexist and is it possible to build an all-embracing model of a megalopolis functioning and development?

The above set of issues clearly shows that the above model should be analyzed and constructed in the frames of interdisciplinary approach. Let me note that a qualitatively significant breakthrough has been achieved on global level. The UNESCO's International Social Science Council has now merged with the International Science Council created a single unified the International Science Council as non-governmental organization (details see at: www.council.science). It means that we are all confronted with the difficulties of converting this decision of international civic organization into a methodology, theory and practice of interdisciplinary field researches. In other words, a world science developing as a process of permanent multiplication of disciplines has to develop a 'reverse move' towards integration of natural, social and technical sciences.

\section{MeTHODOLOGY AND THEORY}

Following Z. Bauman (2018), M. Castells (1996), N. Luhmann (1997), G. Therborn (2000) and I. Wallerstein (2000), I consider our planet as a complex system required interdisciplinary and multidimensional analysis and the mega-cities as the focal points of humanity development.

In this very case I prefer to move simultaneously 'bottom-up' and 'top-down'. That is that is from the changes of the mega-city microstructure toward local community, city as a whole, and then to its regional and global levels and 'top-down' i.e. from the theory and methods of integration of natural, social and technical sciences toward nature-compatible forms of construction and social and political activity. Such double methodological approach is in particular conditioned by the focus of a majority of world-known researchers on general driving forces and trends of globalization as a whole and its various impacts on the megalopolises (Bauman, 2018; Beck, 2015; Bringel and Domingues, 2015;Castells, 1983, 1996;Urry, 2008). The reasons are the following. First, by and large modern societies are becoming an individualized one. Step by step modern state and the transnationals shift a center of gravity and weight of cares onto the shoulders of workers and so-called precariat. Second, a growing mobility of labor power, market and prices oscillations the megalopolises lost their quality of a human community transforming into a guest house for the commuters. The mass influx of involuntary migrants from Africa and the Near East intensify this process. Third, at the same time the gap between the mobile and immobile is growing. This gap has not only material but ethnoconfessional and political character. One part of these migrants looks for shelter and work only while the other part began to participate in urban politics beginning to struggle for their human rights and freedoms. Fourth, an excessive influx of strangers creates an atmosphere of uncertainty and tense in large cities and its aborigines tries to separate from the by all means. Fifth, the very social and political life of mega-cities begin to work as centrifugal force ends in further divergence and separation of the individuals, particular groups, local and global events (summits, congresses, etc.), etc.

But to my mind, the most serious change at the bottom level is the decay of family and kinship as basic units of urban structures. There are many reasons for it: an impact of the media, the propaganda of unisexual marriage, children are outstripping their parents in coping with computer and other gadgets, etc. (the details see in the results of international comparative research project; BüchlerNeiderberger, 2010).Under the impact of cumulative effects of the above forces a decay of a primary eco-structure (Yanitsky, 2012) pick up a speed. It means that the process of destruction of privacy, this basic unit of a western democracy (the cocoon of basic trust, using the A. Giddens definition) is enhances as well. This process is aggravated by the penetration into micro-level unknown people ranging from involuntary migrants to the terrorists and other criminals.

\section{BRIEF HistoricAl VieW}

Conditionally, Russian megalopolises of XVII-XX centuries may be divided into three categories: the capitals of the country, the commercial and industrial centers and the cities as strong points for a mastering of new lands in Siberia and the Far East. But the closer look shows that these three archetypes combined all there functions in one way or another. It's quite understandable because Russia has been always on the move towards the East and the South. By the end of XIX century an integration of three above functions has become absolutely necessary.

The XX century has been extremely turbulent for the reason of two World Wars, revolutionary transformations and civil wars. But it's indicative that in spite of such unfavorable political and social 
conditions there were a lot of attempts to construct and realize a certain model of an 'ideal city.' The reason of such attempts was rather simple: to implement such a model in accordance with dominating ideology that is with an imperial, socialist and capitalist one consequently. But in all cases behind the above ideological premises there was a dominating mode of production and social reproduction.

For example, in the end of XIX century a quick development of capitalist economy set thinking about the quality of living milieu of intensively developed industrial megalopolises. The idea of a 'City of Tomorrow' had been borrowed from the E. Howard's works (Howard, 1902). Russian politicians had visited the Letchworth and some other British new towns (Mizhuev, 1916). More than that, in the year of 1918s, at the beginning of civil war in Russia Vladimir Lenin, the ideologist and leader of Russian revolution had discussed with British novelist Herbert Wells not only the prospects of a new Russian political regime but the prospects of large cities of the world.

The Howard's idea of the cities of tomorrow has an impact on the first ideas of the new regime concerning the reconstruction of Petrograd, in those times the capital of revolutionary Russia. In one of the first decisions of the Petro-soviet of the year of 1918, the executive branch of its government stated that the reconstruction of Petrograd on socialist principles will be based on the Howard's ideas. Besides, the division of mega-cities' space into governmental sector, middle class habitat, industrial zones, suburban summer rest settlements and that of working class and agrarian periphery remain until the end of 1920s. The very facts that in the times of civil war of the years the 1918-22 Russian scientists developed such branch of integrated science as mathematical-biology and stated that the cities should to develop as living organisms: one parts of it has to be destructed and replaced by young growing parts are indicative.

In the end of 1920s it had become obvious that Russia is needed in industrial modernization. An entirely new, socialist type of a city is required. And the 'Discussion on a Socialist City' had been conducted by the Soviet leaders in which took part many outstanding Soviet politicians, scientists, academics, and students as well as the members of many civil society organizations. In particular the participants of the discussion were the members of the Soviet government N. Krupskaya and A. Lunacharsky, architects le Corbusier and Ernst May, many Soviet urban planners and ordinary peoples. It was a unique political and social event never repeated before and after (Kopp, 1967).

The discussion had two streams. The one (and a major one) was a clash between adherents of radical socialization of everyday life of Soviet people and their adversaries (Sabsovitch, 1929). It is indicative that this clash has an echo more than 30 years later, in the years of mass industrial construction of apartment houses and neighborhoods with flats for one family! The other stream was the discussion between the backers of further urbanization and their adversaries, the des-urbanists, the ideologies of so-called 'linear cities.'

In essence, the both parts aimed at making the new cities more healthy and attractive but the former were the adherents of 'collective' mode of living whereas the latter were the backers of individualized one. But an everyday life was conditioned by immediate needs of industrialization and urbanization that was openly seen on the example of building new industrial giants like Magnitogorsk (see for details: Kotkin, 1991). The Soviet leaders took the 'third' decision: to make Moscow, the capital of the Soviet Union a model for all other cities and urban politics at all. A part of the ideologists of this discussion had been repressed.

After the WWII the process of regeneration of destroyed cities has been conducted on the base of rapidly created construction industry. It's necessary to mark that from those timed and afterwards this industry played the role not only as instrument of realization of governmental politics but the further the more had acquired a role of a separate political force throughout the country. The Academy of Architecture of the USSR (later on the Academy of Construction and Architecture) played the leading role creation of this branch of the state politics. In the year of 1954, new Soviet leader N. Chrushchev decided to divide this realm of human activity to an 'architecture' and 'ordinary construction.' Being an architect and urban planner, I was in the midst of this political reconstruction of urban politics in Moscow.

This politics means a total leveling of urban environment by the endless units of standard industriallyconstructed neighborhoods with some unique 'architectural complexes' in a city center symbolizing the Soviet power. To the credit of soviet intelligentsia many ancient building and old cities had been not only protected but carefully restored. In this sphere the intelligentsia played the role of public force. 
In the 1960s the Renaissance of the search of models of future Soviet cities has begun. It has been the period of so-called 'free urbanism' featured by vast open spaces and the attempts to combine a more individualized habitat with the complexes of various services. In those times the 'complexness' has been a keyword of urban politics because the idea of saving and rational use of urban residents' their spare time was dominating. This point resembles a widely accepted view that free-of-work time should be used for family, rest and cultural growth of the Soviet man. And indeed in the 1960-90s educational, cultural and sport spheres had been rapidly grew. It is very important that the majority of the above facilities were practically free of charge.

Then, in the years of so called perestroika many of the above achievements were lost. The life of mega-cities has turned chaos-like. They were full of the jobless, lumpen, street-traders, profiteers and pilferers. Open and overt thuggery flourish.

\section{TRANSFormations In THE MODE OF PrOduction AND ITS CONSEQUENCES}

From the beginning of the 2000s and onwards, megalopolis development marked by total reorganization of urban life on the principles of open market and on political maxima of consumerism. All spheres of urban life have been subjected to accumulation of capital and differentiation of urban dwellers by their income and social position on the power ladder. This new situation has to be analyzed in detail. This transformation has many all-embracing consequences.

To begin with, a minority of population began rapidly grow reach while the majority of population began grow poor. The system of social support of working masses couldn't cover this gap.Large industrial enterprises had closed one by one. A system of individual savings lags far behind an inflation process. The US-oriented national power elite practiced a 'shock therapy' with endless economic and human losses. And time and resources were needed for fundamental restructuring of executive power system on all levels, from the nation-state to municipalities.

A growing gap between the rich and the poor generated a chain of interrelated consequences. Sometimes the Russian society life resembled a kind of the Brownian movement. In addition, the differences between the 'new riches' and rank-and-file people, between those who active and passive, mobile and territorially-fixed, between the satisfied and the hungry, who had shelter and haven't abruptly appeared well-seen and began to influence a political life of the country, first of all in megalopolises and so-called mono-towns, that is the settlements with only one plant and a 'companytown' of its workers and their families.

The above changes exerted a strong influence on the tempo-rhythms and spatial structure of existed megalopolises. Actually, the rich and the poor lived and work in different social spaces. The former quickly have becoming globalists and even internationalists whereas the latter had been forced to be immobile. Or, on the contrary they become the profiteers or in Russian, the sack-commuters. The process of demobilization of the Soviet contingent from the countries of the former Warsaw block had worsened the situation because many of old plants were closed while new ones were quite a few. As a result, the black market flourished. All in all, in that period the survival of Russian society had been backed by gas-oil industry.

It's interesting to mention that one more industry has survived the construction one. Of course, the mass industrial construction of apartment houses had been reduced to minimum while a designing and construction of private houses in suburbs rapidly grew. Accordingly, the system of big state institutes had been replaced by small designing bureaus that closely collaborate with urban dealers.

During the 2000s Russian megalopolises experienced more deep transformations. The process of separation and spatial isolation of the rich and the poor has embraced all Russian mega-cities. A tandem of the designers and dealers began to create and sail self-sustained apartment and individual houses totally isolated from other parts of urban milieu. It's indicative that such estates with the sites of no less than 4 hectares in the midst of historical centers of the mega-cities. Simultaneously rankand-file residents i.e. aborigines of living areas in the city's centers had been resettle to the urban periphery.

In the context of all-embracing individualization of everyday urban life and growing pressure of consumerist ideology it has become much more difficult than ever to call city dwellers to a certain collective action irrespectively of its aims. Urban residents are agreed to act collectively only when it concerns them directly. Volunteers and charity organization still exist but they are not capable exert 
influence on urban policy. The gap between a sustainability as it is and an optimal sustainability is still widening.

There is one more theoretical imperative which has to be taken into account in the analysis of ongoing transformations: an imperative of humanistic turn. Many Russian sociologists of the XIX century (N. Mikchailowsky, M. Kovalewsky, P. Kropotkin) insisted on the necessity of such turn. Later P. Sorokin substantiated the concept of the 'integralism' as a unity of the Truth, Beauty and Good. Recently a humanistic approach is developing by the team of Russian sociologists guided by prof. S. Kravchenko (2018).This approach is recently especially acute from the viewpoint of rapid development of technocratic comprehension of the transition to the Fourth industrial revolution.

\section{AN IMPACT OF IT-COMMUNICATIONS DEVELOPMENT}

This impact has a contradictory effect. On the one hand, it opened to millions urban dwellers the access to new opportunities of work, leisure, medical services, travelling and to many other facilities. On the other hand, the gap between possible opportunities and material possibilities has been widening. Nevertheless, in accordance of recent public surveys about 30\% of young inhabitants of megalopolises intend to emigrate in search of interesting job and higher wellbeing. I think that this figure may grew if some Russian higher schools sponsored by the British Council and other foreign non-governmental organizations will be closed.

But much more principled question has emerged: is a virtual megalopolis is a model of a global megalopolis of a near future? And at the same time as model of interdisciplinary research of global SBT-model? There are some but still not insufficient arguments in favor of the above statements. Let me count some of them. First, by and large an international communication of politicians, academics, business, grassroots and rank-and-file peoples is overlapping the exchange within the boundaries of megalopolises. Second, as it has been already mentioned a local event (case, incident, etc.) may have global consequences and vice versa. Third, the subjects of such contacts are much more diverse resembling local and regional peculiarities of the issues in question. Fourth, it is clear that global contacts allows to conduct comparative researches in many realms and spheres of the global SBTsystem evolution and reveal already existed and potential risks and measures to cope with them. Fifth, simultaneously such global contacts are a necessary prerequisite for balancing of global and local interests. Sixth, it is indicative that the further the more the initiators of such global contacts are becoming civil society organizations. Yes, the idea of global civil society has been suspended but the trend toward it is obviously existed. Seventh, at least the processes of mobilization of civil organizations' resources and involvement in them some municipal and small business units are continued. Or at least an existing domination of technocratic thinking would be reduced. Eights, all in all it seems that the abovementioned trends in virtualization of our life lead to the transformation of existing social institutions into more flexible ones.

But then begin unresolved and inconvenient questions of such transition or what U. Beck called as the 'side-effects' of post modernity. Do the above transformations necessarily lead to the diminishing of natural and social diversity? Do the world gatherings as the Olympic Games or a variety of world festivals are a real convergence of aims and views of general public or the short intermedia between the conflicts, tough competition and wars? Do such world festivals have only demonstrative effects or they serve for making peoples' relations more human? Or more sharp: do such virtual megalopolises assist to such humanization or there are no ways to make tough human competition really more human? It's indicative that G. Therborn in his very deep analysis of types of discourses on nature and character of ongoing globalization only counted a sociocultural approach among five others saying that such sociocultural critics is going in religious or moral terms. A necessity of humanistic approach has not even been mentioned (Therborn, 2000: 152). Besides, the above methodological approach to the analysis of globalization showed the insufficiency of discourse analysis.

\section{Transformation of a Primary ECO-Structure}

This problem is a direct continuation of a previous one. As it has been mentioned earlier, a traditional microcosms (or primary eco-structures, Yanitsky, 2012) like family, kinship or local community are now under pressure of a couple of forces: the feminist and the LGBT movements, the appeals to make 'free love' including unisexual relations of humans, the transgender people, etc.

Recently, situation more complicated. The matter is that such primary eco-structures is under triple pressure of globalization, speeding up an everyday life (more exactly, of its tempo-rhythms) of the 
megalopolises inhabitants and of escaping of children and teenagers from the control of family or kinship. That is an overall existing system of the Enlightenment, education and social control has to be reorganized on the principles of information-based society including a growing impact of massmedia on them. As to situation in Russia, the above transformations are aggravated by a negative impact on schoolchildren behavior exerted by media broadcasting with the scenes of violence, humiliation and killing. The youth is urgently needed in positive examples of human activity aimed at the bettering of natural environment and wellbeing of humanity. To follow the principles of a consumer society under conditions of growing international tension is a deadlock. Finally, the hackers' attacks on the one hand, and the tightening of the legislation related to communication in social networks, on the other, have produced an irritation and protest in the community of the Internet users.

\section{SOCIAL AND OTHER WASTES}

For the first glance, there is no connection between the wastes and the problems of Russian megacities. Indeed, for the long time a mass consuming was very modest, the cars, wears and other thing of everyday use were constructed for years, urban traffic was very modest and packing materials has been produced from natural materials and therefore easy bio-dissolving. In 1960s communist party of the USSR proclaimed the achievement the consumption in accordance with the growing human needed but these needs had been very modest. In that period even so-called advanced population had actually been first of all oriented toward intensive labor, innovations and social approval but not on accumulation of a wealth. And even a majority of mega-cities residents had summer-houses with small plots for growing fruits and vegetables.

In those times the social wastes (pariahs) were absent at all. On the contrary, country experienced a deficit of labor force. A parasitism (sponging) had been punished by law. As to solid wastes, after the WWII an amount of them had been very modest as well because it had been the period of intensive building cities, towns, collective farms, roads, power plants and so on and so forth. Waste disposal, especially radioactive ones deserves special attention.

After the adoption of a consumer society model the situation is sharply changed. Accumulation of solid and food wastes grew quickly. But the matter was not only in their amount but in their quality.

\section{CiVIL SOCIETY ORGANIZATIONS IN RUSSIAN MEGALOPOLISES}

The perestroika years (1987-91) were marked by highest rise of civil activism. The Students' nature protection movement, in Russian it had been called as the Druzhina movement (1988 - the beginning of the 2000s) had been the most massive and network-organized one. As usual, there were ideologically, politically and socially-constructed groups and movements although their life-span had been very short (Yanitsky, 1993; Henry, 2010).

Nowadays, there are many civil society organizations (grassroots, NGOs, funds, ad hoc protest, rescue and volunteers' groups) but they are ideologically, thematically and spatially divided. Besides, the municipalities usually prefer to have 'pocket' grassroots that fulfil urgent deeds in situ. At the same time modern municipalities are the 'filters' which prevent local social activists to participate in municipal elections. The law of the foreign agents is one more such political filter.

There are other circumstances that prevent the growth of civil activism in the mega-cities. A growing mobility of population, the emergence of groups and individuals whose activity do not spatially of temporally fixed (commuters, part-time and distant workers, profiteers, migrants, shuttlers, etc.) make them disinterested in the state of urban environment or/and in participation of local initiative groups struggling for the bettering of their living conditions in situ. The growing gap between the rich and ordinary urban dwellers, encapsulation of the former category in their isolated estate (within the city!) and the mushrooming of ethno-confessional enclaves restricted efforts of civil activists to organize more united urban social movement.

Although, the situation is differed from city to city and an intensity of grassroots activism depends on political stableness and living experience of their leaders as well as from how these groups understand a social and political significance of their activity and, of course, on the risk degree of particular state of matters in situ. Finally, a threatening situation may be created in one place but it consequences will be echoed in quite another. As it is happened with solid wastes which has been produced in Moscow 
but dumped at a distance of about $100 \mathrm{~km}$ near small settlements around the capital. At last, an intensity of civil activism is dependent on the type of an agent - urban environment relationships in a digital age (Misra and Stokols, 2012).

The last case should be analyzed in a more detail. On the one hand, the IT-communications allowed to mega-cities inhabitants to establish contacts across the world and by mean of this to be well-informed (and experienced) in their king of activity and to gain necessary knowledge and financial support. On the other hand, living simultaneously in two worlds, the material and digital ones, make these activists more indifferent and even uprooted in relation to a particular critical or risky situation. In such cases the situations 'here' and 'there' are in opposition with each other.

My studies of Russian environmental movement during 30 years led me to the following conclusions (see, for example, Yanitsky, 1993).Environmental activism in Russian large cities has passed three phases: (1) an emergence of the above Druzhina students' movement with support of academics, teachers and tutors; (2) the rise of all-Russian environmental movement (the EM) in the years of perestroika that put forward political slogans and social demands; and (3) the recent phase characterized by the search of an optimal organizational forms and political demands fit to the transition period toward the digital age. The current years is characterizes by oscillation if the EM leaders between an interest to global issues and to local critical situations. From my viewpoint, the study of political, social and environmental consequences of projects of global scale is the best way for this movement evolution because it allows to study and to protect local milieus in the context of global processes.

As to relationships between state or urban authorities and a mass of ordinary urban residents, they are, as a rule, tense in some degree. The authorities are usually concerned with outer appearance of a city and about the approval of their business activity in the eyes of federal authorities. Urban residents are usually concerned with quality and safety of their everyday life including urban traffic, clean air, running water, etc. The source of this tension is in insufficient development of a city self-government and public participation in resolving current and strategic issues.

\section{In THE SEARCH OF A MODEL OF 'GREen City'}

As it has been mentioned earlier, these searches launched in the very beginning of the XX century. This interest could be explained by two factors. Russians were accustomed to live closely to nature. This 'imperative' could be easily explained by Russian history that developed in a vast and diversified natural milieu. So a majority of Russians are urbanists in the first or second generation only. On the other hand, Russian culture and dominating ideology including the Communist's ones have been transpierced with a 'green' mode of living.

From the Howard's Garden Cities of Tomorrow onwards the 'green idea' dominated because direct contact with nature was seen as inalienable quality of urban life. But recently appears that there are a lot of limits for the realization of this idea. Growth of planet population, lack of such resources as drinking water, energy, food, shelter; expanding gap between reach and the poor countries and their inhabitants, conflicts and wars and so on and so forth.

And here many constructors of our common future make a principled mistake. Instead of the search of means for diminishing the appetites of global capitalism, to make it more human-oriented, they begin to develop various models of an 'ideal megalopolis' forgetting that it is always built in global economic and geopolitical processes. Consumer society cannot be restructured at once. The only way out is to protect the existing biosphere and life on the planet by gradual but uninterrupted reduction of all kinds of natural resources used for production and social reproduction and to intensify the recycling of already produced wastes.

Is it possible? There is at least one way of humanization of the above processes is to develop the sciences and production of chemically and biologically-dissolving already accumulated wastes and creation of a variety of biologically-compatible materials and constructions. All residuals of previous human activity have to be returned into 'normal' biosphere turnover. It allows to humanity to gradually restore an existed metabolism of the biosphere. In other words, humanity is needed to launch a reverse process i.e. the process of transformation of global artificial SBT-system into a nature-like. In this case the biochemistry is coming to the forefront not only as a technical mean but as political and social goals as well. 


\section{CONCLUSION AND DISCUSSION}

In the XX century Russia and the world at large had experienced a set of critical transformations. The shifts from one mode of production to a quite another, a growing dependence of particular economies and political institutions from uncertain and risky global geopolitics, a destruction of habitual mode of living of millions of the earth inhabitants and transition from relatively stable economic and political environment to permanently changing one have been among the most acute political and social challenges. In Russia it had been a multisided 'shock' aggravated by total destruction of the Soviet political machine, loose of existed economic and political ties and shrinking of Russia's territory.

The megalopolises are simultaneously the most sustainable and the most vulnerable SBT-systems because of what is going at national or international geopolitical levels is necessarily influence their structure and development. The same had happened on their local and micro levels. Those politicians who called for radical changes had not the slightest impression about what has to be done on level of urban politics in the period of transition from the state socialism to capitalist mode of production. Russian megalopolises turned from the centers of national economic and social politics into international market centers too quickly. A decade of painful search by the method of trial and error has begun.

The idea of sustainable development adopted by international academic and political community is not yet converted into a strategy and tactics of urban development. It's not still well understandable why the maxima of 'sustainability via permanent changes' developed and empirically confirmed by long-term geopolitical practice has not been adopted. It resulted, to my mind, in growing gap between three interdependent key components of geopolitics, global, nation-state and urban ones.

The experience of two last decades showed that Russian megalopolises are still the most livable geopolitical and cultural SBT-systems. Despite many impediments of national and international origin (periodical economic crises, sanctions, and overall global geopolitical instability) these systems remain relatively sustainable due to their capability to adapt to domestic and international challenges. It allows to civil organizations and academic community not only to dealt with current difficulties but to develop models of 'green mega-cities' for the future (Ermolaeva, 2018).

In order to surmount divergence and isolation trends in Russian megalopolises a set of interrelated tasks should be posed and resolved. These mega-cities will become more sustainable if their role will be clearly defined in the program of strategic Russia's development for the coming 15-20 years. To my mind, it should be humanistic-oriented program of transition to digitally-grounded mode of production and consumption and to safety and wellbeing of urban population. Then the divergence between the rich and the poor should be not only mechanically reduced but both sides should be involved in resolving of the above tasks. In turn it means that rank-and-file urban dwellers have to participate in the development of any urban programs and to be interested in their material and social results. Otherwise, the tension between the rich and rank-and-file urban dwellers will continue to grow.

But the tempo-rhythms of global-local development are quickening every day. It means that a set of urgent issues have to be discussed in political and academic community in a near future. I indicate here only a few of them. As I. Wallerstein predicted 20 years ago, current globalization is entering in an 'age of transition' burdened by chaotic 'behavior which will cause a systemic bifurcation and a transition to a new structure whose nature is yet undetermined' (Wallerstein, 2000:249). Second, how simultaneously to reduce substantively the wastes produced by modern megalopolises and to protect cultural diversity of them, to maintain a balance between their local, national and international units? Third, how to reconcile two adversarial trends namely to maintain an economic growth and to minimize energy consumption? Fourth, in what degree existing technological structures including the megalopolises might be replaced by nature-like and nature-dissolved materials and substances? Fifth, is the Vernadsky's idea of creation of 'the 'autotrophy of humanity' (Vernadsky, 1980) could be practically realized?

And the final and the most urgent questions: what has to be done for explaining to all parts of humanity that the abovementioned integration of natural, social and technical sciences is urgently needed? And what will be then the relationships between an integrated science and competing political wills both regulating the life on our planet? 


\section{REFERENCES}

[1] Bauman Z. 2018. A Chronicle of Crisis: 2011-2016, with the preface by Dr. N. Lawson. London, UK: Social Europe Edition. ISBN 978-1-9997151-0-6

[2] Beck U. 1999.World Risk Society. Malden, MA: Polity Press.

[3] Beck U. 2015. Emancipatory Catastrophism: What does it mean to Climate Change and Risk Society? Current Sociology, 63 (1): 75-88.

[4] Bringel B. and Domingues J., eds. 2015.Global Modernity and Social Contestation. SAGE: Los Angeles, London, New Delhi, Singapore, Washington DC.

[5] Büchler-Neiderberger D. 2010.Childhood Sociology - Defining the State of Arts and Ensuring Reflection. Current Sociology, 58 (2): 155-163.

[6] Castells M. 1983. The City and the Grassroots. A Cross-cultural Theory of Urban Social Movements. London: EdwardArnold, Ltd.

[7] Castells M. 1996. The Information Age. Economy, Society and Culture. Oxford: Blackwell Publishers, Ltd.

[8] Ermolaeva P. 2018.Russian mega-cities in the context of new social and environmental challenges. Available at: https://russiansustainablecities.wordpress.com/

[9] Henry L. 2010. Red to Green. Environmental Activism in Post-Soviet Russia. Ithaca and London: Cornell University Press.

[10] Howard E. 1902. The Garden Cities of Tomorrow. London.

[11] Kopp A. 1967. Ville et revolution. Architecture et urbanisme sovietique des annees vingt. Paris.

[12] Kravchenko S., ed. 2018. Humanistic turn: An imperative of human civilization. Moscow: 'MGIMOUniversity' Publishing House.

[13] Kotkin St. 1991. Steeltown, USSR: Soviet Society in Gorbachev Era. California: University of California Press.

[14] Luhmann N. 1993. Risk: A Sociological Theory. N.Y.: Aldine de Gruyter, Inc.

[15] Misra S., Stokols D. 2012.A typology of people-environment relationships in the digital age.Technology in Society, 34: 311-325.

[16] MizhuevP. 1916. Garden-cities and housing issue in England. Petrograd: Suvorin's publ. house (in Russ.).

[17] Sabsovitch L. 1929. On cities of tomorrow and the organization of socialist mode of life. Moscow (in Russ.).

[18] Sassen S. 1991. The Global City. Princeton, NJ: Princeton University Press.

[19] Sassen S. 2000. Territory and Territoriality in the Global Economy, International Sociology, Vol. 15 (2): 372-393.

[20] Therborn G.2000. Globalizations: Dimensions, Historical Waves, Regional Effects, Normative Governance. International Sociology, Vol. 15 (2): 151-179.

[21] Urry J. 2008.Mobilities. Cambridge: Polity Press.

[22] Vernadsky V. 1980.Problems of a geochemistry. Works of biogeochemical laboratory. Moscow: Nauka (in Russ.).

[23] Wallerstein I. 2000.Globalization in the Age of Transition.International Sociology, Vol 15 (2): 249-265.

[24] Yanitsky O. 1993. Russian Environmentalism: Leading Figures, Facts, Opinions. Moscow: MezhdunarodnyeOtnosheniya Publishing House.

[25] Yanitsky, O. 2012. A Primary Eco-Structure: The Concept and its Testing. Social Analysis, Vo.2 No 2, pp. 7-24.

[26] Yanitsky O. 2016. Sociobiotechnical systems: a New Approach to Man-Nature Interactions, in: Yanitsky O.On Globalization and its Environmental Consequences. Moscow: IS RAS' pp. 123-135. Available at: http://www.isras.ru/index.php?_id1198\&id=4603

Citation: Oleg Yanitsky. “ Russian Megalopolis: Processes of Divergence, Separation and Integration of its Agents". International Journal of Political Science (IJPS), vol4, no.3, 2018, pp.5-13. doi:http://dx.doi.org/10.20431/2454-9452.0403002.

Copyright: (C) 2018 Authors. This is an open-access article distributed under the terms of the Creative Commons Attribution License, which permits unrestricted use, distribution, and reproduction in any medium, provided the original author and source are credited. 